\title{
IAMJ
}

INTERNATIONAL

AYURVEDIC

MEDICAL JOURNAL

Review Article

ISSN: 2320-5091

Impact Factor: 6.719

\section{UNDERSTANDING THE ROLE OF KAPHA IN URUSTHAMBHA AND ITS CHIKITSA}

\author{
$\underline{\text { Swathi }}^{1}$, G Srinivasa Acharya ${ }^{2}, \underline{\text { Aniruddha }}^{3}, \underline{\text { Shrilatha Kamath }}^{4}$
}

${ }^{1} 3^{\text {nd }}$ year PG scholar, ${ }^{2}$ Professor \& Ex Principal, ${ }^{3}$ Associate Professor, ${ }^{4}$ Professor \& HOD, Department of PG studies in Kayachikitsa \& Manasaroga, SDMCA, Udupi, Karnataka, India

Corresponding Author: swathikekuda8894@gmail.com

\section{https://doi.org/10.46607/iamj1309072021}

(Published Online: July 2021)

Open Access

(C) International Ayurvedic Medical Journal, India 2021

Article Received: 10/06/2021 - Peer Reviewed: 15/06/2021 - Accepted for Publication: 18/06/2021

Check for updates

\section{ABSTRACT}

Lifestyle diseases are the burning problem today. The disease-causing lifestyles are Gramya achara, Apatarpana achara and Santarpana achara. The diseases which are caused due to such acharas are called lifestyle diseases. This is usually caused by unhealthy dietary habits and lack of physical exercise, leading to excess generation of Kapha and Medas. When this Kapha and Medas start accumulating in various parts of the body, it leads to Vyadhisankara / Aupasargika roga. Aupasargika roga includes Purvothpanna vyadhi / Purvarupa vyadhi and Upadrava vyadhi. Such type of Aupasargika roga is Urusthambha where the pathology can be divided into Purvarupa and Upadrava. Chikitsa also follows the pathology of the disease. The same has been attempted to capture in the below conceptual study.

Keywords: Santarpana achara, Aupasargika roga, Urustambha, Purvarupa Vyadhi, Upadrava vyadhi, Kapha, Meda.

\section{INTRODUCTION}

Gramya achara, Apatarpana achara, Santarpana achara are the three lifestyles that lead to diseases. These lifestyles cause either an increase in the negative energy balance in the human body and make person Krusha (Emaciated) or raise positive energy balance turning individual into Stoulya (Obesity). In case of raise in positive energy, excessive conservation, and accumulation of energy in the form of Medas (fat) starts in the body along with Kapha. Later this accumulated Meda and Kapha leads to a plethora of 
diseases like Prameha, Prameha pidaka, Vatavyadhi, etc $^{1}$. Amidst them, is the Urustambha. When this Kapha and Medas lodges in Uru pradesha vitiating Vata and forming Ama, storage of fat increases further with diminished utilization of it. Subsequently, person develops severe Stambha in the Uru and finds difficulty in walking and leads to Urustambha ${ }^{2}$. The condition Urustambha is best treated with pacifying of Kapha and Medas by Rukshana, Kshapana and Shamana Chikitsa. Kapha is naturally seated in Rasa, Medas and other Dhatus. Based on Ashrayaashrayee bhava the morbidity of Kapha also leads to vitiation of Dhatu in which it is seated. Due to the similarity in the qualities between Kapha and Medas, Kapha dosha exhibits affinity to afflict Medo dhatu as mentioned in Chikitsa of Prameha. It is worth mentioning that Medoroga is narrated as a characteristic of Sleshma prakruthi by Acharya Sharangadhara. Hence, we can say that there is strong bonding between Kapha and Medas and many times it is used as synonymous. In Sushrutha Samhita it has been mentioned that the first stage of the disease which has manifested early leading to the next stage of the disease is Aupasargika. Here the first stage of pathology is considered as Purvarupa vyadhi and the second stage of pathology is considered as Upadrava vyadhi ${ }^{3}$. In Urustambha pathology can be classified into two different stages. In the first stage, there is Kapha medho vriddi and Amarasa formation (Purvarupa vyadhi) whereas the second stage of Urustambha is characterized by Avarana janya vatavyadhi (Upadrava vyadhi).

Nidana: Lifestyle consisting of consumption of ample number of nutritious foods in combination with day sleep and lack of exercise leads to overnutrition, which is referred to as Santarpana achara ${ }^{4}$. Charaka and other Acharya have highlighted Santarpana achara such as Gramya mamsa, Anupa mamsa, Audaka mamsa Rasa, Snigdha, Guru, Sheetala aharasevana, Adyashana, Divaswapna, Atinidra, Pistavikaras, Atimadya, Atisneha ${ }^{5}$ etc as aetiology for Urustambha. Samprapti: Excessive and repeated consumption of nutritious food in combination with lack of physical exercise and day sleep and other Santarpana achara leads to the additional generation of Kapha resulting in Rasagata ama. This Rasagata ama which is formed has properties such as Madhura (sweet) and Atisnehata (greasy) and aids in excessive production of, Medha dhatu ${ }^{6}$ (Purvarupa vyadhi). This unwarranted Meda dhatu subsequently vitiates Vata and blocks the movement of Vata and due to its Drava guna, Gouravata, Sheetata as well as Prithvi and Ap mahabhutha predominance it travels down and gets settled in Uru along with Tridoshas and affect the Sira dhamani (Upadrava vyadhi). So as the Nidana continues Kapha and Medas go on increasing in Uru affecting the Sira dhamani srotas leading to Urustambha ${ }^{7}$.

\section{Lakshana:}

Poorvarupa vyadhi lakshana of Urustambha: Nidra adikya, Sthimithya, Gourava, Aruchi, Jvara, Lomaharsha, Chardhi, Sheetata, Janga uru sadana ${ }^{8}$ are the clinical features manifested by Kapha, Medas and Ama.

Upadrava vyadhi lakshana of Urustambha: Vedana, Supthi, Kampana, Toda, Beda, Spurana, Ruja, Angamarda, Daha ${ }^{9}$ etc are the clinical features manifested because of obstruction to the movement of Vata.

Panchakarma nisheda: The reasons for contraindication of Panchakarma in Urustambha are the formation of Rasagata ama, immobility of Kapha and Avarana by Kapha and Medas. As per Chikitsa of Ama, Shodana is contraindicated. Due to Sthira guna of Kapha, it does not possess the ability to move towards the Kosta alone. Hence it is dependent on Vata for its movement towards Kosta for Shodana. As in the case of Avarana, the movement of Vata is obstructed by Kapha and Medas. Hence without the removal of Kapha and Medas from Sira dhamani strotas, Srotoshodana is not possible. As Panchakarma and Snehapana are Nisheda one can use Anupashaya of Snehapana to diagnose the stage of Urustambha. If at all it is in Purvarupa vyadhi stage, performing Snehapana exhibits symptoms like Pada sadana supti etc feature ${ }^{10}$ Hence both Panchakarma and Samanya vata Chikitsa does not hold good in case of Purvarupa stage of Urustambha. 
Chikitsa: Patients suffering from Urustambha should take therapy, medicines and meals which alleviate Kapha, and which do not aggravate Vata and also protecting patient's Shareera, Bala and Agni ${ }^{\mathbf{1 1}}$ Based on pathology, Chikitsa of Urustambha is divided into 2 aspects i.e. Chikitsa at Purvarupa vyadhi avasta and Upadrava vyadhi avasta. The main principles of Purvarupa vyadhi chikitsa include Shamana / Kshapana / Shoshana ${ }^{12}$.

Rukshana/Shoshana: (Drying up of Kleda by absorption or increasing the mobility of Kleda) with Yava (barley), Shyamaka (millet), and Kodrava along with vegetables cooked with water and oil, but without adding salt. One can also opt for Kshaara prayoga, Arista prayoga, Haritaki prayoga, Madudaka prayoga and Pippali yoga ${ }^{13}$.

Kshapana of Kapha can be done by Bahya upacharas like Valmeekamruthikadi utsadana, Ashwagandhadi utsadana, Dantyadi pralepa, Tarkaryadi sechana, Sarshapa pralepana, Vatsakadi pralepana, Shyonakadi sechana and Pralepa. Also, by adopting few lifestyle measures such as Vigorous physical exercise, walking over the ground covered with sand in the morning, walking over the ground covered with gravels in the morning, climbing hilly mountains, swimming often against the current of river with cold water, swimming frequently in a pond having clean, cold and stable water ${ }^{14}$. One can also plan for Kshapana by Abhyantara upachara, following Pathya and Shamanaushadi prayoga. Pathya should be followed by changing the food to Shyaamaka, Kodrava, Uddaala, and Shaali which are Purana (stored before 1 year or more) this Purana dhanyas will subside the Kapha and Medas. Yusha of Shuska Moolaka or Patola, Jangala mamsa rasa and vegetables without ghee and salt is beneficial keeping in mind the common rule ${ }^{15}$.

Shamana prayoga can be selected accordingly with Rasa prayoga, Basma prayoga, Churna kalpana, Vati, Kwatha, Aasava / arista, Taila prayoga.

Upadrava vyadhi chikitsa which is the second pathology of Urustambha are to be followed after Purvarupa vyadhi chikitsa. In this stage both
Panchakarma as well as Samanya vatavyadhi chikitsa can be followed

Meralgia Paresthetica: Meralgia paresthetica is a common condition often misdiagnosed because of mimicking other conditions. Impingement of the lateral femoral cutaneous nerve is defined as meralgia paresthetica. The symptoms of meralgia include numbness, burning, stabbing, and multiple bees stings like pain. The course of pain begins along the welldelineated path of the LFCN from the front of the thigh to just above the knee. Meralgia paresthetica most often occurs in 30 to 40 years old individuals with a reported incidence rate of 4.3 cases per 10,000 patients yearly in the general population. Pregnancy, obesity, alcoholism, diabetes, and other external causes usually turn to be the aetiology. Treatment -Vigorous physical exercise, NSAIDS, Surgery ${ }^{16}$.

Spinal epidural lipomatosis: Spinal epidural lipomatosis is defined as a pathological overgrowth of the normally presented extradural fat and often causes Dural impingement. It is a rare entity to cause spinal cord compression and neurological deficits. Usually associated with excess steroid consumption or morbid obesity and in many idiopathic ${ }^{17}$.

\section{DISCUSSION}

Santarpana janya vyadi or lifestyle disorders is an umbrella term quoted to a plethora of diseases that which is the outcome of following excess of Santarpana achara. Urustambha is explained before the management of Vatavyadhi in Charaka Samhita. This is the clue given by our Acharya that all Vatavyadhi cannot be treated with Snehana, Swedana or Samanya vatavyadhi chikitsa. Few of the diseases even being Vatavyadhi using the Yukti one should think of the Nidana behind the disease and clear the Nidana first and then go for the Vatavyadhi chikitsa. Hence the next chapter of Vatavyadhi chikitsa starts with Kevala nirupastambham. This means when there is only Vata without the involvement of other Doshas one can go for Vatavyadhi chikitsa and confirms the involvement of Kapha and Medas in the Purvarupa stage of Urustambha and later leading to Vatavyadhi. Treatment here is much focussed on reducing Kapha 
and Medas so an alternative to the lifestyle measures is aquatic exercise. Which are easy \& more efficient to perform the exercise in water.

\section{CONCLUSION}

Urustambha is a Santarpanota janya vyadhi. It is Kapha medho vriddi janya vyadhi. It can also be considered under the heading of Vyadhi sankara / Aupasargika roga of Vatavyadhi where the pathology of the Urustambha can be divided into Purvarupa vyadhi and Upadrava vyadhi. There is a prominent role of Kapha as well as Medas in the Purvarupa stage of Urustambha. In this stage of disease, Panchakarma is Nisheda and Samanya vatavyadhi chikitsa is contraindicated. Kshapana, Rukshana and Shamana play an important part in the treatment by alleviating Kapha. Hence this accomplishes that both in manifestation and treatment of Urustambha, Kapha has a significant role to play.

\section{REFERENCES}

1. Acharya Dalhana. Acharya Sushrutha. Vaidya Jadavji Trikamji Acharya and Narayanaram Acharya editor. Sushrutha Samhita with Nibandha Sangraha commentary. Varanasi: Choukhambha Sanskrit Sansthan; 2005.p.73.

2. Acharya Chakrapani dutta. Acharya Agnivesha. Acharya Charaka.Yadavji Trikamji Acharya editor. Charaka Samhita with Ayurveda Dipika commentary. Varanasi: Choukhambha Surbharati Prakashan; 2019.p.613.

3. Acharya Dalhana. Acharya Sushrutha. Vaidya Jadavji Trikamji Acharya and Narayanaram Acharya editor. Sushrutha Samhita with Nibandha Sangraha commentary. Varanasi: Choukhambha Sanskrit Sansthan; 2005.p.128.

4. Acharya Dalhana. Acharya Sushrutha. Vaidya Jadavji Trikamji Acharya and Narayanaram Acharya editor. Sushrutha Samhita with Nibandha Sangraha commentary. Varanasi: Choukhambha Sanskrit Sansthan; 2005.p.73.

5. Acharya Chakrapani dutta. Acharya Agnivesha. Acharya Charaka.Yadavji Trikamji Acharya editor. Charaka Samhita with Ayurveda Dipika commentary. Varanasi: Choukhambha Surbharati Prakashan; 2019.p.613.
6. Acharya Dalhana. Acharya Sushrutha. Vaidya Jadavji Trikamji Acharya and Narayanaram Acharya editor. Sushrutha Samhita with Nibandha Sangraha commentary. Varanasi: Choukhambha Sanskrit Sansthan; 2005.p.73.

7. Acharya Chakrapani dutta. Acharya Agnivesha. Acharya Charaka.Yadavji Trikamji Acharya editor. Charaka Samhita with Ayurveda Dipika commentary. Varanasi: Choukhambha Surbharati Prakashan; 2019.p.613.

8. Acharya Chakrapani dutta. Acharya Agnivesha. Acharya Charaka.Yadavji Trikamji Acharya editor. Charaka Samhita with Ayurveda Dipika commentary. Varanasi: Choukhambha Surbharati Prakashan; 2019.p.613.

9. Acharya Chakrapani dutta. Acharya Agnivesha. Acharya Charaka.Yadavji Trikamji Acharya editor. Charaka Samhita with Ayurveda Dipika commentary. Varanasi: Choukhambha Surbharati Prakashan; 2019.p.613-614.

10. Acharya Chakrapani dutta. Acharya Agnivesha. Acharya Charaka.Yadavji Trikamji Acharya editor. Charaka Samhita with Ayurveda Dipika commentary. Varanasi: Choukhambha Surbharati Prakashan; 2019.p.614.

11. Acharya Chakrapani dutta. Acharya Agnivesha. Acharya Charaka.Yadavji Trikamji Acharya editor. Charaka Samhita with Ayurveda Dipika commentary. Varanasi: Choukhambha Surbharati Prakashan; 2019.p.614.

12. Acharya Chakrapani dutta. Acharya Agnivesha. Acharya Charaka.Yadavji Trikamji Acharya editor. Charaka Samhita with Ayurveda Dipika commentary. Varanasi: Choukhambha Surbharati Prakashan; 2019.p.615.

13. Acharya Chakrapani dutta. Acharya Agnivesha. Acharya Charaka.Yadavji Trikamji Acharya editor. Charaka Samhita with Ayurveda Dipika commentary. Varanasi: Choukhambha Surbharati Prakashan; 2019.p.614.

14. Acharya Chakrapani dutta. Acharya Agnivesha. Acharya Charaka.Yadavji Trikamji Acharya editor. Charaka Samhita with Ayurveda Dipika commentary. Varanasi: Choukhambha Surbharati Prakashan; 2019.p.614.

15. Acharya Chakrapani dutta. Acharya Agnivesha. Acharya Charaka.Yadavji Trikamji Acharya editor. Charaka Samhita with Ayurveda Dipika commentary. 
Varanasi: Choukhambha Surbharati Prakashan; 2019.p.615.

16. https://www.slideshare.net/mobile/AdeWijaya5/meral gia-paresthetica-94872005

17. https://www.ncbi.nlm.nih.gov/pmc/articles/PMC30879 97/

\section{Source of Support: Nil}

\section{Conflict of Interest: None Declared}

How to cite this URL: Swathi et al:Understanding The Role Of Kapha In Urusthambha And Its Chikitsa. International Ayurvedic Medical Journal \{online\} 2021 \{cited July 2021\} Available from: http://www.iamj.in/posts/images/upload/1404_1408.pdf 